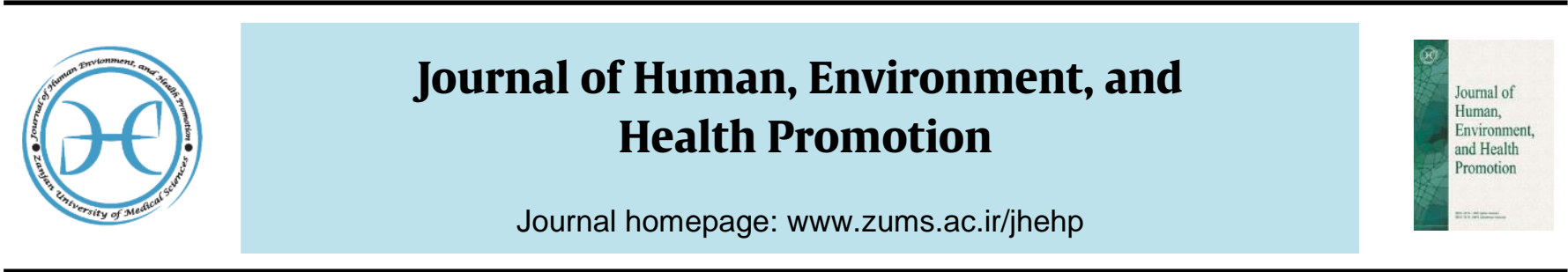

\title{
Seasonal Variations of Cadmium and Lead Concentrations in Water, Sediments, and Tissues of Fish in Mellat Artificial Lake, Iran
}

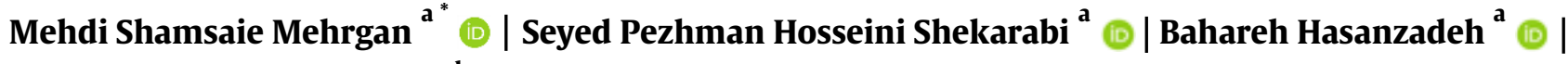 \\ Seyed Hadi Seyed Alhosseini ${ }^{\text {b }}$
}

a. Department of Fisheries Science, Science and Research Branch, Islamic Azad University, Tehran, Iran.

b. Department of Fisheries, Faculty of Marine Natural Resources, Khorramshahr University of Marine Science and Technology, Khuzestan, Iran.

${ }^{*}$ Corresponding author at: Department of Fisheries Science, Science and Research Branch, Islamic Azad University, Tehran, Iran. Postal code: 1477893855.

E-mail address: m.shamsaie@srbiau.ac.ir

\section{A R T I C L E I N F O}

\section{Article type:}

Original article

\section{Article history:}

Received: 23 August 2019

Revised: 3 November 2019

Accepted: 23 November 2019

DOI: 10.29252/jhehp.5.4.6

\section{Keywords:}

Mellat lake

Cadmium

Lead

Heavy metals

Sediment

\begin{abstract}
A B S T R A C T
Background: The present study aimed to determine the concentrations of cadmium $(\mathrm{Cd})$ and lead $(\mathrm{Pb})$ in water, bottom sediments, and tissues of sampled fish from Mellat artificial lake in Iran.

Methods: Two stations were selected to evaluate the heavy metal concentrations, including the IRIB qanat (S1) and middle part of the lake (S2). The measurements were performed in triplicate via flame atomic absorption spectroscopy.

Results: In water, the highest levels of $\mathrm{Pb}(5.33 \mathrm{mg} / \mathrm{l})$ and $\mathrm{Cd}(0.650 \mathrm{mg} / \mathrm{l})$ were observed in the sampled sediments from S2 in autumn and winter, respectively $(P<0.05)$. Seasonal analysis revealed that the highest and lowest $\mathrm{Pb}$ concentrations were in the fish muscles in summer $(8.107 \mathrm{mg} / \mathrm{kg})$ and spring $(0.487 \mathrm{mg} / \mathrm{kg})$, respectively, while the fish liver showed the maximum $(3.982 \mathrm{mg} / \mathrm{kg}$ ) and minimum $\mathrm{Pb}$ concentrations $(0.690 \mathrm{mg} / \mathrm{kg})$ in autumn and winter, respectively. The $\mathrm{Pb}$ concentration in the fish muscle and liver was above the standard limits for human consumption. However, the Cd level in the fish muscle in spring was below the standard limits, which gradually increased and exceeded the standard limits.

Conclusion: Precautions are required to avoid the contamination of Mellat Lake with heavy metal-based sources due to the discharge of pollutants.
\end{abstract}

\section{Introduction}

Contamination of biotic and abiotic components with heavy metals may affect all forms of life and lead to dire consequences in animal and human health $[1,2]$. The type of heavy metals and their impact on public health differ from their permissible limits. For instance, elements such as cadmium, arsenic, mercury, and lead are biologically unnecessary and could be toxic for living organisms even at extremely low concentrations [3]. Furthermore, essential minerals (e.g., silver, copper, and zinc) in excess amounts may result in toxicity for the consumers [4].

Heavy metal concentrations in aquatic ecosystems are often monitored by measuring their concentrations in water, sediments, and the associated biota [5]. Heavy metals could be transferred through aquatic food webs and accumulate in living organisms [2,6], which in turn exerts antagonistic effects and causes various human and animal diseases [3]. 
Cadmium ( $\mathrm{Cd}$ ) and lead $(\mathrm{Pb})$ are the most common elements with regard to heavy metal toxicity in aquatic ecosystems, which are considered alarming globally [7]. Lead is a toxic heavy metal that causes numerous complications in the neurological system and has high concentrations in urban areas due to the combustion of leaded petrol [8]. The importance of the bioaccumulation of cadmium in aquatic animal tissues and biomagnification of this element in water, sediments, and aquatic food chain have been reported in some studies in this regard [9]. In addition, several studies have indicated that cadmium is a carcinogenic substance, which may adversely affect human kidney function and significantly increase the risk of breast, prostate, colon, rectal, kidney, and lung cancer [10]. Reports have also denoted the presence of these metals in Buriganga River in Bangladesh [11] and Musa estuary in the Persian Gulf in Iran, while their geo-accumulation has also been reported in summer and winter [12].

In a study in this regard, Wildi et al. (2004) stated that the lakes and reservoirs located in the downstream of the urban areas in Switzerland have been polluted with cadmium, lead, chromium, mercury, and cobalt, and the main environmental risk was the remobilization of the contaminants and their return to the food chain [13]. In another study, lead and cadmium concentrations were measured in the muscles, liver, and gill tissues of common carp from Beyșehir Lake in Turkey, and the results indicated that the concentrations of these heavy metals reached the highest value in summer and winter. On the other hand, the samples evaluated in spring and autumn had the lowest heavy metal concentrations [14]. In another research, Iqbal and Munir (2014) reported the distribution of some heavy metals in various tissues of common carp in Rawal Lake, which is an urban artificial reservoir in Pakistan [15].

Mellat Lake is located in the northeast of Tehran (Tehran, Iran) and was built in 1966. The lake is an attraction to the local visitors and recreational fishermen owing to its location in Tehran metropolis. Moreover, the stored water behind the lake is the main source of the irrigation of the garden.

The present study aimed to assess lead and cadmium contamination in the water, sediments, and tissues of the Cyprinidae fish family in Mellat lake as one of the largest artificial lakes in Tehran.

\section{Materials and Methods}

\subsection{Description of the Study Area}

Mellat artificial urban lake is located in Mellat Park, which is the municipal green space in Tehran, occupying an area of approximately 220 hectares in the northeast of Tehran metropolis. The geographical state of the lake is $35^{\circ} 46^{\prime} 45^{\prime \prime} \mathrm{N}$ and $51^{\circ} 24^{\prime} 35^{\prime \prime E}$, and the water is supplied by qanats, precipitations, and runoff.

\subsection{Sample Collection}

Sampling was performed from the water, sediments, and fish seasonally during March 2016-March 2017. Two stations (S1 and S2) were selected in Mellat artificial lake (Figure 1) to evaluate the effects of seasonal variations on heavy metal concentrations. The S1 station (IRIB qanat) was selected considering the water inlet to the lake, and the S2 station was selected in the middle of the lake to represent the possible significant pollution sources.

The water samples were collected using the methods recommended by the United States Environmental Protection Agency (USEPA). In summary, water samples were collected using sterile bottles $(50 \mathrm{ml})$, which were immediately stored at the temperature of $4 \pm 1^{\circ} \mathrm{C}$ before laboratory analysis (less than 4 hours). The samples were filtered through the Whatman filter paper No. 42 to eliminate unwanted objects (e.g., wood pieces, plants, and other particles). In total, three samples were collected from each station to determine the heavy metal concentrations on the same date at the depth of 1.5 meters seasonally.

The bottom sediments were sampled using an Ekman bottom grab sampler seasonally based on the recommended EPA methods. Sampling was performed at the depth of 3-4 meters in triplicate for each time in order to obtain an appropriate portion of the sediments. Following that, the samples were wet-sieved through a fivemillimeter mesh to remove the plant fragments [16]. The settled sediments were washed with methanol and hexane to obtain homogeneous samples and dried in open air prior to the digest process.

The fish specimens were caught through gillnetting (mesh size: $65 \mathrm{~mm}$ ) and transferred to the science and research laboratory in ice. The sampled fish belonged to the Cyprinidae fish family, and the total length (TL) and body weight (BW) of the samples were measured (Table 1). In addition, the fish tissues (muscles and liver) were obtained and stored in the refrigerator (less than 48 hours) for heavy metal contamination analysis.

All the animal procedures were performed in accordance with the ethical guidelines of the Science and Research University and international guidelines for the care and use of animals for scientific research.

\subsection{Determination of Heavy Metals}

The collected fish samples were dried in an oven at the temperature of $105^{\circ} \mathrm{C}$ and transferred to a furnace oven at the temperature of $550^{\circ} \mathrm{C}$. Afterwards, one gram of the dried fish samples was mixed with $65 \%$ nitric acid $(10 \mathrm{ml})$ and heated at the temperature of $140^{\circ} \mathrm{C}$ for three hours. The digestion process was completed when all the samples were totally dissolved in the acid. Following that, the digested samples were filtered through a filter paper (Whatman No.1, Maidstone, UK) and preserved at the temperature of $4^{\circ} \mathrm{C}$ until the analysis of the heavy metal concentrations in the solution via flame atomic absorption spectrophotometer (FAAS) [17]. Moreover, triplicate digestion was carried out for each sample seasonally.

Water digestion was performed by mixing 100 milliliters of the sampled water with five milliliters of $5 \mathrm{M}$

Table 1: Body Weight (BW) and Total Length (TL) of Sampled Fish from Mellat Lake

\begin{tabular}{lcc}
\hline Season & \multicolumn{2}{c}{ Biometric characteristics } \\
\cline { 2 - 3 } & TL $(\mathbf{m m})$ & BW $(\mathbf{g})$ \\
\hline Spring & $336.0 \pm 59.4$ & $331.6 \pm 80.8$ \\
Summer & $316.3 \pm 76.5$ & $301.8 \pm 62.3$ \\
Autumn & $291.2 \pm 68.6$ & $285.2 \pm 69.2$ \\
Winter & $286.6 \pm 52.1$ & $264.6 \pm 48.3$ \\
\hline
\end{tabular}




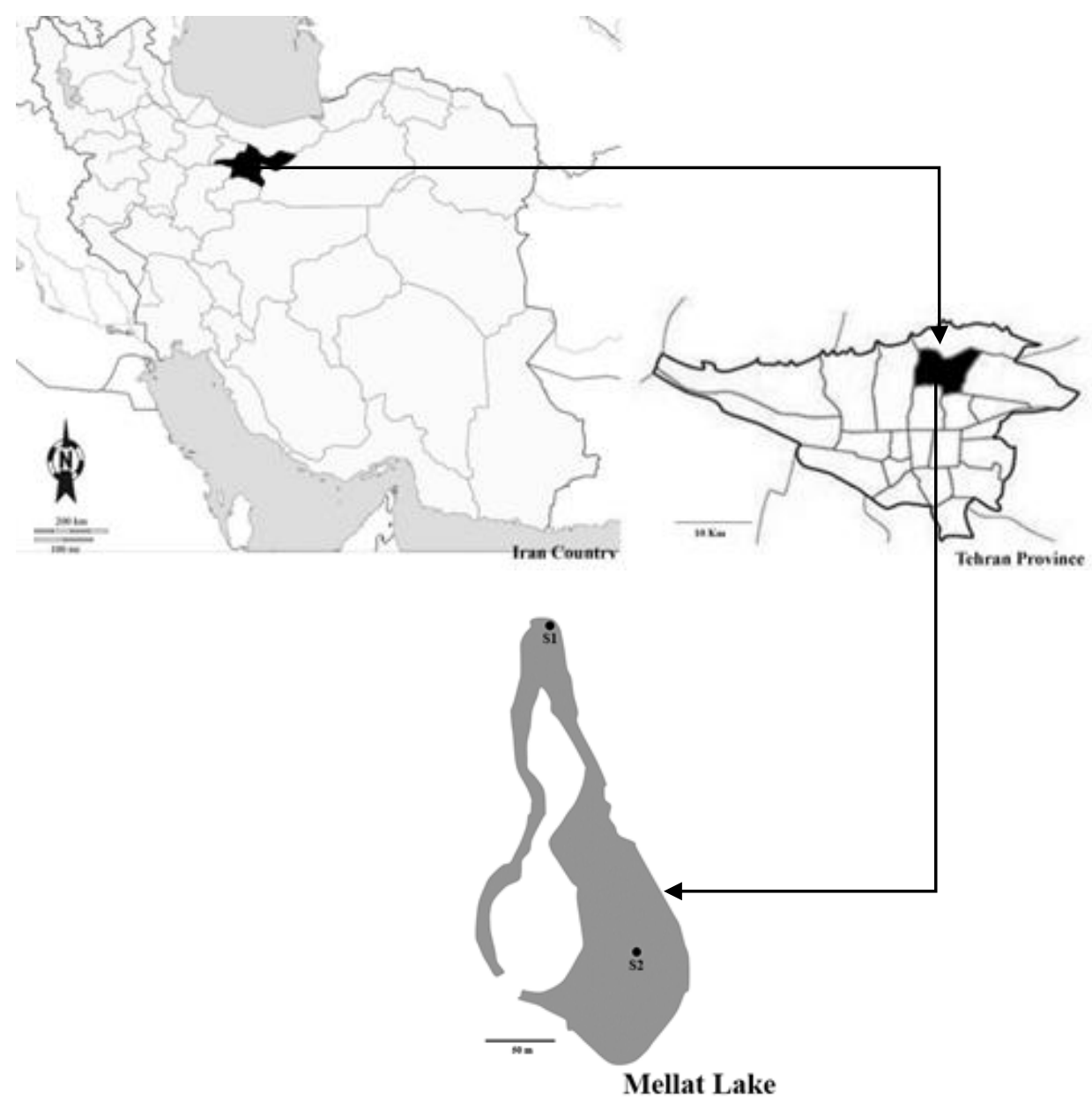

Figure 1: Location of Study Area and Sampling Stations (S1 and S2)

hydrochloric acid. Afterwards, the digestion process was completed by heating the solution at the temperature of $105^{\circ} \mathrm{C}$ for two hours. At the next stage, double distilled water was added to the solution to obtain the final volume of 100 milliliters, and the solution was used for the AAS analysis.

For the digestion of the sampled sediments, one gram of the sediment samples was dried and transferred to a digestion tube $(250 \mathrm{ml})$, and five milliliters of $65 \%$ hydrochloric acid was added, along with six milliliters of $37 \%$ hydrochloric acid, which were heated at the temperature of $120^{\circ} \mathrm{C}$ for three hours. The digested sediments were cooled, filtered (Whatman No. 42, Maidstone, UK), and diluted up to 25 milliliters using double distilled water.

\subsection{Detection of Cadmium and Lead Concentrations}

In the present study, AAS was used to determine the cadmium and lead concentrations in various digested samples using an atomic absorption Varian Spectra AA-200 spectrophotometer (Varian, Australia) in accordance with the instructions of the manufacturer, and hollow cathode lamps (Cathodeon) were used as the energy sources. The optical density of cadmium and lead were estimated at 228 and 217 nanometers, respectively.

\subsection{Statistical Analysis}

Data analysis was performed in SPSS version 22, and the results were expressed as the mean and standard error. The statistical differences in the heavy metal concentrations between water, sediments, fish tissues, and stations in different seasons were determined using one-way analysis of variance (ANOVA) at the significance level of 0.05 .

\section{Result and Discussion}

Table 2 shows the seasonal variations in lead and cadmium concentrations in the water and sediment samples collected from Mellat Lake. Accordingly, the highest lead level in the S1 was observed in spring (mean: $0.1550 \pm 0.1151 \mathrm{mg} / \mathrm{l}$ ), while the highest lead concentration in the S2 was observed in summer (mean: $0.085 \pm 0.0088$ $\mathrm{mg} / \mathrm{l}$ ). Meanwhile, the lowest lead concentration in the S1 and S2 was obtained in winter, and the highest lead level (mean: $5.332 \pm 0.147 \mathrm{mg} / \mathrm{l}$ ) in the sediments was observed in autumn. The minimum lead level in the sediments was recorded in spring (mean: $0.820 \pm 0.035 \mathrm{mg} / \mathrm{l}$ ). 
Table 2: Seasonal Concentrations of Lead and Cadmium ( $\mathrm{mg} / \mathrm{l})$ in Water (S1 and S2) and Sediment Samples of Mellat Lake

\begin{tabular}{|c|c|c|c|c|c|c|}
\hline \multirow[t]{2}{*}{ Season } & \multicolumn{3}{|c|}{$\mathrm{Pb}(\mathrm{mg} / \mathrm{L})$} & \multicolumn{3}{|c|}{$\mathrm{Cd}(\mathrm{mg} / \mathrm{L})$} \\
\hline & S1 & $\mathrm{S} 2$ & Sediment & S1 & S2 & Sediment \\
\hline Spring & $0.155 \pm 0.115^{a}$ & $0.042 \pm 0.012^{b}$ & $0.820 \pm 0.035^{d}$ & $0.001 \pm 0.000^{b}$ & $0.006 \pm 0.000^{\mathrm{a}}$ & $0.011 \pm 0.001^{\mathrm{b}}$ \\
\hline Autumn & $0.045 \pm 0.0107^{b}$ & $0.050 \pm 0.010^{b}$ & $5.332 \pm 0.147^{a}$ & $0.001 \pm 0.000^{b}$ & $0.001 \pm 0.000^{b}$ & $0.072 \pm 0.007^{b}$ \\
\hline Winter & $0.007 \pm 0.000^{c}$ & $0.007 \pm 0.008^{c}$ & $1.170 \pm 0.051^{c}$ & $0.000 \pm 0.000^{b}$ & $0.001 \pm 0.000^{b}$ & $0.654 \pm 0.071^{\mathrm{a}}$ \\
\hline
\end{tabular}

According to the obtained results, the highest cadmium concentration was recorded in the S1 (mean: $0.009 \pm 0.000$ $\mathrm{mg} / \mathrm{l}$ ) and S2 (mean: $0.017 \pm 0.000 \mathrm{mg} / \mathrm{l}$ ) in summer. On the other hand, the lowest concentration of cadmium was observed in the S1 (mean: $0.000 \pm 0.000 \mathrm{mg} / \mathrm{l}$ ) and S2 (mean: $0.001 \pm 0.000 \mathrm{mg} / \mathrm{l}$ ) in winter. The maximum concentration of cadmium in the sediment samples was obtained in winter (mean: $0.654 \pm 0.071 \mathrm{mg} / \mathrm{l}$ ), while the minimum cadmium concentration in the sediments was reported in spring (mean: $0.011 \pm 0.001 \mathrm{mg} / \mathrm{l}$ ).

According to the information in Table 3, lead concentration had a significant difference in the muscles and liver of the sampled fish. In addition, the highest lead levels were observed in the muscle (mean: $8.107 \pm 0.395$ $\mathrm{mg} / \mathrm{kg}$ ) and liver tissues (mean: $3.982 \pm 0.338 \mathrm{mg} / \mathrm{kg}$ ) in summer and autumn, respectively. The minimum lead concentration was detected in the muscle (mean: $0.487 \pm$ $0.028 \mathrm{mg} / \mathrm{kg}$ ) and liver tissues (mean: $0.690 \pm 0.044 \mathrm{mg} / \mathrm{kg}$ ), which were recorded in spring and winter, respectively. However, no significant difference was observed in the cadmium level between the muscle and liver tissues of the sampled fish in spring. The highest cadmium concentration in the muscle (mean: $0.25 \pm 0.048 \mathrm{mg} / \mathrm{kg}$ ) and liver tissues (mean: $0.26 \pm 0.026 \mathrm{mg} / \mathrm{kg}$ ) of the fish was observed in summer and winter, respectively, while the lowest cadmium levels (mean: $0.05 \pm 0.004 \mathrm{mg} / \mathrm{kg}$ and $0.05 \pm 0.000$ $\mathrm{mg} / \mathrm{kg}$, respectively) were denoted in spring $(P<0.05)$.

Cadmium and lead are classified as non-essential elements, and their high concentrations may be detected in aquatic organisms due to anthropogenic activities. The toxicity of these heavy metals (even at low levels) has been confirmed in humans and animals. The present study revealed the correlations between the seasonal variations and environmental contamination degree with heavy metals in water, sediments, and fish tissue samples ( $C$. carpio) in Mellat Lake.

According to the findings of the current research, the highest lead concentration was observed in the S1 and S2 in spring and summer, respectively, while the lowest lead concentration in the S1 and S2 was obtained in winter. The highest cadmium concentration was recorded in the S1 and S2 in summer, and the lowest cadmium concentration was observed in the S1 and S2 in winter.

The higher levels of these heavy metals during summer may be due to dry weather, which results in higher evaporation and decreased precipitation [14]. Consistently, Obasohan and Eguavoen (2008) reported that dry seasons are associated with the increased accumulation rate of heavy metals in water and stocked fish [18].

According to the literature, lead exerts various detrimental effects, including neurotoxicity and nephrotoxicity, rapid behavioral malfunction, reduced growth and metabolism, and changes in the social behavior of some mammals [19]. In the present study, the highest lead concentration was observed in the water samples in spring and sediments in autumn. The lowest values were measured in winter and spring in the water and sediment samples, respectively. In this regard, the World Health Organization (WHO), Food and Agriculture Organization (FAO), and EPA have cooperatively set the limit of 5-10 mg/l for the lead concentration allowed for agricultural irrigation purposes [20]. Correspondingly, neither S1 nor S2 exceeded the mentioned limit.

According to the results of the present study, the cadmium concentration in the water samples was highest in summer and lowest in winter, which could be due to the increased human activities and dry weather, affecting the environment of Mellat Lake directly or indirectly. In a research in this regard, Zyadah (1995) reported that the seasonal fluctuations of heavy metals in Lake Manzala (Egypt) may be due to the variations in the agricultural drainage water, sewage effluents, and industrial wastes that are discharged into the lake [21]. Furthermore, Ali and Abdel Satar (2005) observed the highest heavy metal concentrations in the water in fish farms (El-Fayoum, Egypt) in warm seasons (spring and summer) due to the overlying of water and release of heavy metals from sediments to water columns [22].

The results of the present study indicated that the accumulation pattern of the heavy metals in water was proper for irrigation based on the EPA guidelines (2002) [3]. Meanwhile, cadmium is toxic even at low concentrations $(0.1 \mathrm{mg} / \mathrm{l})$ and has the capacity to accumulate in soil and animal tissues. Therefore, water with low contents of cadmium should not be recommended even for the irrigation of plants [23]. Heavy metals such as cadmium could interact with cytoplasmic components (e.g., enzymes) and adversely affect metallothionein (MT) function [24]. In the current research, the cadmium level in the fish muscles in spring was below the standard limits, while it gradually increased and exceeded the standard limits in summer .

Sediments are considered to be a proper indicator of heavy metal contamination in the monitoring of these pollutants in aquatic environments [4,7]. 
Table 3: Seasonal Concentrations of Lead and Cadmium ( $\mathrm{mg} / \mathrm{kg})$ in Muscle and Liver Tissues of Sampled Fish from Mellat Lake

\begin{tabular}{|c|c|c|c|c|}
\hline \multirow[t]{2}{*}{ Season } & \multicolumn{2}{|c|}{$\mathrm{Pb}(\mathrm{mg} / \mathrm{kg})$} & \multicolumn{2}{|c|}{ Cd (mg/kg) } \\
\hline & Muscle & Liver & Muscle & Liver \\
\hline Spring & $0.487 \pm 0.028^{c}$ & $1.150 \pm 0.087^{b}$ & $0.05 \pm 0.004^{b}$ & $0.05 \pm 0.000^{b}$ \\
\hline Summer & $8.107 \pm 0.395^{a}$ & $3.1505 \pm 0.410^{a}$ & $0.25 \pm 0.048^{a}$ & $0.12 \pm 0.080^{a}$ \\
\hline Autumn & $1.57 \pm 0.225^{b}$ & $3.982 \pm 0.338^{a}$ & $0.15 \pm 0.010^{\mathrm{ab}}$ & $0.20 \pm 0.018^{a}$ \\
\hline Winter & $0.500 \pm 0.050^{c}$ & $0.690 \pm 0.044^{c}$ & $0.14 \pm 0.021^{\mathrm{ab}}$ & $0.26 \pm 0.026^{a}$ \\
\hline
\end{tabular}

Different letters on each column indicate a significant difference between treatments $[\mathrm{n}=3 ; P<0.05]$

Heavy metals in water bodies plunge and precipitate at the bottom, thereby becoming part of the sediment component. High heavy metal contents could be detected from the base $\mathrm{pH}$ value $(\mathrm{pH}=7.40-8.59)$ at the location where the metal is difficult to dissolve and settle [25], which in turn leads to the reduction of bottom-dwelling organisms (e.g., shrimp, crab, and mussels) due to heavy metal toxicity [9]. In the present study, the sediments accumulated heavy metals more than water. This is in line with the findings of Ibrahim and Omar (2013) in the Nile River (Asyut Governorate, Egypt) [26], Davies et al. (2006) in the Bonny River (Elechi Creek, Nigeria) [27], and Eja et al. (2003) in the Great Kwa River (Nigeria) [28].

In a study in this regard, Tekinm Özan and Aktan (2012) recorded the cadmium concentrations in the sediments of Işılı Lake (Turkey), which was estimated to be within the range of $0.19-3.06 \mathrm{mg} / \mathrm{l}$; the proposed values are lower compared to the current research [14]. On the other hand, Al Saadi et al. (2002) reported the highest concentrations of lead, copper, and cadmium in spring in the sediments of Lake Habbaniyah (Iraq) [29]. However, our findings demonstrated that the maximum concentrations of lead and cadmium were in the sediment samples in autumn and winter, respectively, which could be attributed to the seasonal amounts of urban runoff. The permissible limit of cadmium in sediments is $1.5 \mathrm{mg} / \mathrm{kg}$ based on the Australian Interim Sediment Quality Guidelines (ISQG) and $3.53 \mathrm{mg} / \mathrm{kg}$ according to the EPA. Moreover, the safety level for lead in sediments has been set at $50 \mathrm{mg} / \mathrm{kg}$ in the ISQG, while the WHO recommends that lead concentration should not surpass $0.3 \mu \mathrm{g} / \mathrm{g}$ (wet weight basis), with the recommended lead limit determined to be 450 micrograms per day for adults [30]. In the present study, the concentrations of cadmium and lead in the sampled sediments were below the threshold risks.

The content of heavy metals in aquatic biota often increases through lifespan and bioaccumulation, so that water biota could be used as reliable indicators for heavy metal pollution. In addition, there is a strong correlation between MT expression and environmental heavy metals in fish tissues that high exposure to heavy metals, induces MT synthesis to help the fish in detoxification of these elements [24].

Heavy metal concentrations in the tissues of freshwater fish vary considerably in different studies, which could be due to the physiological role of each organ, feeding habits, ecological needs, metabolism, age, and size of fish $[1,4,6,9]$. According to the current research, the highest level of accumulated lead in the liver and muscles were observed in summer and autumn. On the other hand, the minimum value of lead was detected in spring and winter. Mellat Park is located in Tehran, which is the capital of Iran and rated as one of the most polluted cities in the world. As such, higher levels of lead are often detected in the water bodies near highways and large cities due to high gasoline combustion.

\section{Conclusion}

In this study, the concentrations of heavy metals were determined in different compartments of Mellat Lake in Tehran, Iran. According to the results, the water samples had the highest lead concentration in spring, while the lowest concentration was observed in winter. In addition, the highest level of lead was measured in the bottom sediments in autumn and winter. Heavy metal accumulations were higher in the liver tissues of the sampled fish ( $C$. carpio) compared to the muscle samples. The maximum and minimum levels of lead in the liver tissue samples of the fish were measured in autumn and winter, respectively. On the other hand, the highest and lowest cadmium levels in the fish muscles were recorded in summer and spring, respectively.

Considering the high concentration of lead in the fish muscle and liver tissues (above the permissible limits for human consumption), the use of the lake water for recreational purposes and fishing may be detrimental to human health. Therefore, it is recommended that quality control indices be taken into account due to the low concentrations of the studied heavy metals in the studied lake. Furthermore, efforts are required to reduce the runoff of these heavy metals into Mellat Lake.

\section{Authors' Contributions}

M.Sh.M., created the conception and design of the work. Corresponding author; S.P.H.S., and B.H., and S.H.S.A., analyzed the data, drafted the manuscript; and revised the manuscript. All authors approval the final version to be published.

\section{Conflict of Interest}

There is not a direct or indirect conflict of interest in the context or content of this study.

\section{Acknowledgments}

Hereby, we extend our gratitude to the staff of the Science and Research Laboratory for their cooperation and technical assistance in this research project (Project No. 32415).

\section{References}

1. Malik N, Biswas AK, Qureshi TA, Borana K, Virha R. Bioaccumulation of Heavy Metals in Fish Tissues of A Freshwater Lake of Bhopal. Environ Monit Assess. 2010; 160: 267-76. 
2. Janbakhsh S, Hosseini Shekarabi SP, Shamsaie Mergan M. Nutritional Value and Heavy Metal Content of Fishmeal from the Southwest Caspian Sea. Casp J Environ Sci.2018; 16: 307-17.

3. Environmental Protection Agency. Mercury in Water by Oxidation, Purge and Trap, and Cold Vapor Atomic Fluorescence Spectrometry. United States Environmental Protection Agency, USA; 2002.

4. Ambedkar G, Muniyan M. Analysis of Heavy Metals in Water, Sediments and Selected Freshwater Fish Collected from Gadilam River, Tamilnadu, India. Int J Toxicol Appl Pharmacol. 2012; 2: 25-30.

5. Camusso M, Vigano L, Baitstrini R. Bioaccumulation of Trace Metals in Rainbow Trout. Ecotox Environ Safe. 1995; 31: 133-41.

6. Schmitt C, Brumbaugh W. Accumulation of Metals in Fish from Lead-Zinc Mining Areas of Southeastern Missouri. Ecotox Environ Safe. 2007; 67: 14-30.

7. Islam MS, Ahmed MK, Raknuzzaman M, Al Mamun MH, Islam MK. Heavy Metal Pollution in Surface Water and Sediment: A Preliminary Assessment of an Urban River in a Developing Country. Ecol Indic. 2015; 48: 282-91.

8. Agency for Toxic Substances and Disease Registry. Toxicological Profile for Lead. Us Department of Health and Human Services. Public Health Service. Agency for Toxic Substances and Disease Registry, Atlanta, USA; 1988 .

9. Jayaprakash M, SenthilKumar R, Giridharan L, Sujitha SB, Sarkar SK, Jonathan MP. Bioaccumulation of Metals in Fish Species from Water and Sediments in Macrotidal Ennore Creek, Chennai, Se Coast of India: a Metropolitan City Effect. Ecotox Environ Safe. 2015; 120: 243-55.

10. Bernard A. Cadmium and Its Adverse Effects on Human Health. Indian J Med Res. 2008; 128(4): 557-64.

11. Saha PK, Hossain, MD. Assessment of Heavy Metal Contamination and Sediment Quality in the Buriganga River, Bangladesh. In Proceeding: $2^{\text {nd }}$ International Conference on Environmental Science and Technology. IPCBEE, Singapore. 2011; 6: 384-8.

12. Safahieh A, Abdolahpour Monikh F, Savari A, Doraghi A, Ronaghm MT. Spatial and Seasonal Variations of Heavy Metals Concentration in Sediment, Musa Estuary (Persian gulf). Indian J Mar Sci. 2014; 43: 84957.

13. Wildi W, Dominik J, Loizeau JL, Thomas RL, Favarger PY, Haller L, et al. River, Reservoir and Lake Sediment Contamination by Heavy Metals Downstream From Urban Areas of Switzerland. Lakes Reserv Res Manag. 2004; 9: 75-87.

14. Tekin Özan S, Aktan N. Relationship of Heavy Metals in Water, Sediment and Tissues With Total Length, Weight and Seasons of Cyprinus Carpio L, 1758 From Işikli Lake (Turkey). J Zool. 2012; 44: 1405-16.

15. Iqbal I, Munir H. Study of Seasonal Variations and Health Risk Assessment of Heavy Metals in Cyprinus Carpio from Rawal Lake, Pakistan. Environ
16. Ben Salem Z, Laffray X, Al Ashoor A, Ayadi H, Aleya L. Metals and Metalloid Bioconcentrations in the Tissues of Typha Latifolia Grown in the four Interconnected Ponds of a Domestic Landfill Site. J Environ Sci. 2016; 54: 56-68.

17. Ranasinghe P, Weerasinghe S, Kaumal MN. Determination of Heavy Metals in Tilapia Using Various Digestion Methods. Int J Sci Res Inno Technol. 2016; 3: 38-48.

18. Obasohan EE, Eguavoen OI. Seasonal Variations of Bioaccumulation of Heavy Metals in a Freshwater Fish (erpetoichthys calabaricus) from Ogba River, Benim City, Nigeria. Afr J Agric Res. 2008; 4: 153-63.

19. Garcia Leston J, Mendez J, Pasaro E, Laffon B. Genotoxic Effects of Lead: an Updated Review. Environ Int. 2010; 36: 623-36.

20. Ayers RS, Westcott DW. Water Quality for Agriculture. FAO Irrig Drain. 1985; $29: 1-120$.

21. Zyadah M. Environmental Impact Assessment of Pollution in Lake Manzalah and its Effect on Fishes. Ph.d. Dissertation. Mansoura, Egypt: Mansoura University; 1995.

22. Ali MH, Abdel Satar AM. Studies of some Heavy Metals in Water Sediment, Fish and Fish Diets in Some Fish Farms in El-Fayoum Province, Egyptian. J Aquat Res. 2005; 31: 261-73.

23. Rowe DR, Abdel Magid IM. Handbook of Wastewater Reclamation and Reuse. London, UK: Lewis Publishers; 1995.

24. Coyle P, Philcox JC, Carey LC, Rofe AM. Metallothionein: the Multipurpose Protein. Cell Mol Life Sci. 2002; 59: 627-47.

25. Hutagalung HP, Setiapermana D, Riyono SH. Sea Water Analysis Method. Jakarta, Indonesia: Puslitbang Oseanologi; 1997

26. Ibrahim AA, Omar HM. Seasonal Variation of Heavy Metals Accumulation in Muscles of the African Catfish Clarias Gariepinus and In River Nile Water and Sediments at Assiut Governorate, Egypt. J Biol Earth Sci. 2013; 3: $236-48$

27. Davies OA, Allison ME, Uyi HS. Bioaccumulation of Heavy Metals in Water, Sediment and Periwinkle (tympanotonus fuscatus var radula) from the Elechi Creek, Niger Delta. Afr J Biotechnol. 2006; 5: 968-73.

28. Eja ME, Ogri ORA, Arikpo GE. Bioconcentration of Heavy Metals in Surface Sediments from the Great Kwa Rivers Estuary, Calabar, South Eastern Nigeria. J Nigerian Environ Soc. 2003; 2: 247-56.

29. Al Saadi HA, Al Lami AA, Hassan FA, Aldulymi AA. Heavy Metals in Water, Suspended Particles, Sediments and Aquatic Plants of Habbaniya Lake, Iraq. Int J Environ Stud. 2002; 59: 589-98.

30. Chi QQ, Zhu GW, Alan L. Bioaccumulation of Heavy Metals in Fishes from Taihu Lake, China. J Environ Sci. 2007; 19: 1500_4.

How to cite: Shamsaie Mehrgan M, Hosseini Shekarabi SP, Hasanzadeh B, Seyed Alhosseini SH. Seasonal Variations of Cadmium and Lead Concentrations in Water, Sediments, and Tissues of Fish in Mellat Artificial Lake, Iran. J Hum Environ Health Promot. 2019; 5(4): 177-82. 